\title{
ESTÉTICA Y HERMENÉUTICA DE LA IRRUPCIÓN FESTIVA: DEVOCIÓN DEL NIÑOPA EN XOCHIMILCO
}

THE AESTHETICS AND HERMENEUTICS OF FESTIVE IRRUPTION: THE DEVOTION OF NIÑOPA IN XOCHIMILCO

\author{
María Cristina Ríos Espinosa ${ }^{1}$ \\ ORCID 0000-0003-0331-936X
}

Universidad del Claustro de Sor Juana

Ciudad de México, México

\section{Resumen}

El objetivo de este artículo es mostrar cómo la estetización ritual del Niñopa, celebrada en Xochimilco, México, el 2 de febrero de cada año, desde su instauración por los misioneros franciscanos en el siglo XVI hasta nuestros días, es una manifestación exuberante de resistencia política, de práctica ritual "contrahegemónica". Esta investigación es pertinente en el campo de la poética-estética y hermenéutica de la liberación, y los estudios de la decolonialidad. La metodología de análisis es multidisciplinaria, se recuperarán algunas de las categorías teóricas de la filosofía de la liberación de Enrique Dussel, las empleadas por Bolívar Echeverría en su filosofía de la cultura y del antropólogo y etnógrafo Félix Báez, para aplicarlas a nuestro objeto de estudio. Se trata de probar dos hipótesis, 1) es un caso de "contrahegemonía ritual" frente al catolicismo institucional y, si es así, sería un error ubicar la devoción del Niñopa como expresión del "catolicismo popular"; 2) es una práctica de "criptoreligiosidad-indoamericana" en el sentido de oculto y prohibido disfrazado de un signo cristiano hegemónico y vencedor, como es la imagen de un santo, así como un fenómeno de mestizaje simbólico de supervivencia identitaria conocido como ethos barroco.

Palabras clave: Estética-hermenéutica de liberación, criptoreligiosidad-indoamericana, ritualidad contrahegemónica, ethos barroco.

\section{Resumo}

O objetivo desse artigo é mostrar a maneira em que a estetização ritual do Niñopa, celebrada em Xochimilco, México, em 2 de fevereiro de cada ano, desde o seu estabelecimento pelos missionários franciscanos, no século XVI, até os dias atuais, é uma manifestação exuberante de resistência política e uma prática ritual "contra-hegemônica". Esta pesquisa é condizente com o campo da poiética-

\begin{abstract}
The aim of this article is to demonstrate how the aesthetic rituality of the Niñopa festivities in Xochimilco - which has been celebrated every year on $2^{\text {nd }}$ February since the $16^{\text {th }}$ Century to date- is a representation of political resistance, a contra-hegemonic ritual practice. This research is highly relevant in the field of philosophy of liberation, in particular in the poetic-aesthetics and hermeneutics
\end{abstract}


estética e hermenêutica, e os estudos da descolonialidade. A metodologia de análise é multidisciplinar: são recuperadas algumas das categorias teóricas da filosofia de libertaçáo de Enrique Dussel, aquelas empregadas por Bolívar Echeverría em sua filosofia da cultura, e pelo antropólogo e etnógrafo Félix Báez, para aplicá-las em nosso objeto de estudo. Proponho duas hipóteses: 1) Trata-se de um caso de "contra-hegemonia ritual" contra o catolicismo institucional e, nesse caso, é um erro localizar a devoçáo do Nińopa como expressáo do "catolicismo popular"; 2) Trata-se de uma prática de "criptoreligiosidade indo-americana" no sentido de oculto e proibido, disfarçada com um signo cristão hegemônico e vitorioso - tal e como acontece com qualquer imagem de um santo -, e também de um fenômeno de miscigenação simbólica de sobrevivência indentitária conhecida como ethos barroco.

Palavras-chave: Estética-hermenêutica da libertaçáo, cripto-religiosidade indo-americana, ritualidade contrahegemônica, ethos barroco. of liberation and also in decolonial studies. We will follow a multidisciplinary methodology, as in our study we will apply theoretical categories drawn from Enrique Dussel's philosophy of liberation, Bolívar Echeverría's philosophy of culture and anthropologist and ethnographer Félix Báez's categories. We will seek to prove two hypotheses: 1) the Nińopa festivities are an example of "contrahegemonic rituality" facing against institutional Catholicism, in which case it would be a mistake to consider this ritual practice as an expression of "popular Catholicism". 2) this ritual is an example of "Indo-American crypto-religion" in the sense that the occult and the forbidden appear in the guise of a hegemonic and victorious Christian sign, such as the effigy of a saint, and it is also a symbol of the identity melting pot known as ethos of the Baroque.

Keywords: Aesthetics and Hermeneutics of Liberation, cryptoindigenous-religious-practice, contrahegemonic rituality, ethos of the Baroque.

El objetivo de este artículo es probar si la estetización ritual del Niñopa, celebrada en Xochimilco el 2 de febrero de cada año, es una manifestación exuberante de resistencia política, de práctica ritual "contrahegemónica" en el sentido de cómo una comunidad se hace dueña de sus propias formas de sociabilidad e intercambio de bienes, no de mercancías, una estética devocional alrededor de la cual los miembros de la comunidad giran. El tiempo festivo es prioritario frente al secular, de ahí que la ritualidad sea la base de su organización económica, distribución prioritaria hacia el tiempo sagrado adonde van dirigidos todos los esfuerzos cotidianos de la comunidad en lugar de al tiempo profano dominado por las relaciones mercantiles productivistas basadas en la competencia a las cuales se encuentran sometidas las periferias latinoamericanas. 
Esta investigación es pertinente en el campo de la filosofía de la liberación, en particular en una poiética-estética y hermenéutica de la liberación, pero, también, en la teoría de la decolonialidad en la medida en que esta práctica devocional dedicada al Nińopa por la comunidad xochimilca en México la considero un caso ejemplar de "contrahegemonía ritual" frente al catolicismo institucional y, por lo tanto, es un error ubicarla como una expresión del "catolicismo popular", es una hermenéutica y estética analéctica ${ }^{1}$ decolonial debido a que su ritualidad es la expresión de una cosmovisión a partir del rostro negado de la alteridad, de un Otro negado en sus formas de simbolización primordiales y leales a sus creencias fundacionales, las cuales ayudan a sus miembros a construir su identidad, sus lazos de amistad y compromiso con el sentido de su comunidad, cruzado por la emotividad de los afectos como expresión de su sensibilidad, lo que permite resistencia a la alienación y fragmentación pues su corporalidad deja de estar entregada a los imperativos del capitalismo y a la represión del trabajo. Se trata de una práctica ancestral más allá de su mestizaje simbólico con el cristianismo, se enmarca dentro del calendario religioso católico de "La Candelaria", sin embargo, toda la estética simbólica religiosa tiene una hermenéutica fundada en los mitos mexicas quienes conquistaron a los xochimilcas y sincretizaron este culto al niño Huitzchilopztli, quien deja su huella en la masa de maíz y eso significa la palabra "Niñopa", el niño del lugar (pa) o niño "pan" (dios) se trata del mito fundacional del nacimiento de Huitzilopoztli en común denominador con los dioses solares mesoamericanos. La práctica devocional del Niñopa permite una liberación del tiempo y del espacio, una temporalidad hierofánica en donde la comunidad expresa sus afectos, su amor, empatía, compañerismo, fe, confianza, esperanza y, al hacerlo, los devotos del Niñopa en su fiesta patronal ofrecen sus corporalidades a un tiempo mítico y a fines de vida ajenos a los constreñimientos impuestos por el capitalismo, bajo cuyo dominio se encuentran las sociedades poscoloniales, la práctica permite romper con las formas de vida cotidianas: de entrega sacrificada al trabajo, de inversión y ruptura del tiempo ordinario dominado por la prisa, la escasez y la suspensión de la forma de vida capitalista como acumulación de riqueza. Los orígenes de estas prácticas devocionales de los santos están basadas en la relación de la comunidad con la naturaleza, la cual no es vista como

1 La investigación se enmarca dentro de la filosofía de la liberación tomando de ella la categoría dusseliana de "anadialéctica operativa" o "analéctica" que consiste en describir, analizar, teorizar a partir de nuestros saberes como periferia latinoamericana, desde la "ana" (negación), es decir, desde nuestro rostro negado podemos producir prácticas poiéticas-epistémicas y realizar "la práxis de liberación histórica, real, la que cumple con el pueblo y que es objeto central de nuestra reflexión" (DUSSEL, 1995, p. 96). Se trata de pensar desde nuestros propios saberes, en el caso de nuestro objeto de estudio desde la estética devocional del Nińopa como prácticas y saberes de la periferia alienada y explotada epistémica, semiótica y económicamente en una clara imposición ideológica. 
un espacio para usufructuar producción, como en la concepción europea y anglosajona moderna de naturaleza, como Dussel crítica en Filosofía de la producción al decir:

Este modo de descubrir la naturaleza como stock lo lleva a situarse ante ella agresivamente, sólo para obtener, transformar, acumular, repartir, consumir [...] definiremos esta actitud como "explotabilidad", es decir, el europeo sitúa a la naturaleza (y aún a otros hombres) como meras mediaciones explotables (lo que vale porque puede dar algo de sí ante el acto de exprimir, extraer, sacar, robar) para el proyecto de "estar-en-la-riqueza" (DUSSEL, 1985, p. 65).

En apariencia la estética devocional de los santos en México se enmarca dentro del triunfo ideológico espiritual de la conquista espiritual de América, pero un análisis etnográfico, antropológico y filosófico más profundo nos muestra fundamentos "contrahegemónicos", como, por ejemplo, la "indigenización de los santos" como muestra Félix Báez-Jorge en "Las hagiografías populares y la religiosidad en el México indígena” (BAEZ-JORGE, 2015), un mestizaje simbólico de supervivencia como demuestra Bolívar Echeverría en su La modernidad de lo barroco (ECHEVERRÍA, 2000) y una "estética-hermenéutica de liberación" siguiendo la categoría empleada por Enrique Dussel en su Filosofía de la producción (DUSSEL, 1985).

Hipótesis y metodología de análisis

Se trata de probar 1) si estamos frente a un caso ejemplar de "contrahegemonía ritual" frente al catolicismo institucional y, si es así, sería un error ubicar la devoción del Niñopa como expresión del "catolicismo popular" y, por lo tanto, estamos frente a una estética y hermenéutica de la liberación; 2) si dicha devoción "contrahegemónica" es una práctica enmarcada dentro de lo que denominaremos "criptoreligiosidad-indoamericana" y un mestizaje simbólico de supervivencia identitaria en aquello que Bolívar Echeverría denominaba el ethos barroco en La modernidad de lo barroco; 3) si esta devoción "contrahegemónica" es una "estética de la disipación", un potlach a la mexicana, en donde el dispendio de bienes útiles es una forma de ostentación de poder, deben desecharlos porque la comunidad cree que los objetos poseen el espíritu de su creador y el retenerlos y acumularlos puede dańar a su poseedor, por eso cada ańo hay que ofrecérselos al santo patrono, en este caso, el Niño Jesús, como si los dioses necesitaran o fuesen sensibles a su estetización visual por parte de la comunidad para recibir, a cambio de este dispendio material de bienes útiles, una estetización simbólica de abundancia y protección divina durante todo el año calendario hasta su próxima celebración el 2 de febrero, día de la Candelaria. Pero además la 
necesidad de su circulación entre la comunidad para conservar la tradición y unidad social entre los xochimilcas, ser mayordomo es un gran honor y son capaces de esperar 34 o 40 ańos para serlo, la lista de espera es larga.

La estetización ${ }^{2}$ ritual del Niñopa sería una forma necesaria de dispendio festivo para volver tolerable lo que la vida ordinaria dentro del sistema capitalista hace imposible, al exigir una corporalidad entregada al sacrificio de su mercantificación, una contradicción que los miembros de una sociedad aceptan de ordinario si es que desean sobrevivir en el sistema. Los hay de dos tipos: los que se dan cuenta de su contradicción al convertir su trabajo en mercancía para ser vendida en la dinámica del mercado, una "conciencia enajenada para sí”, como la llama George Lukács, vive esta situación como un drama existencial, porque sabe lo que hace; a diferencia de este, están aquellos que enajenan su corporalidad como "conciencia en sí", es decir, no se saben en contradicción, fluyen con el sistema y ni siquiera se lo cuestionan.

La metodología de análisis de la investigación es multidisciplinaria, emplea estudios antropológicos y etnográficos de las hagiografías de los santos en México, categorías de la filosofía de la liberación de Enrique Dussel, hermenéutica de la cultura de Bolívar Echeverría y teoría estética de la cotidianidad de Katya Mandoki. Se buscará aplicar este corpus teórico a nuestro objeto de estudio, las prácticas devocionales del Niñopa en Xochimilco.

Fundamento "idoloclasta" de las imágenes devocionales de los Santos y el mestizaje simbólico de las imágenes cristianas en la Nueva España.

Las imágenes de Vírgenes y Santos en las costas del golfo de México, en primera estancia, con la llegada de Cortés entre 1517 y 1519 y luego en México-Tenochtitlan, Tlaxcala y Xochimilco con la labor misionera franciscana, llevaban en sí mismas la "negación del adversario" (GRUZINSKI, 1994), el "ocultamiento del indio" como dice Enrique Dussel,

Los indios ven negados sus propios derechos, su propia civilización, su cultura, su mundo [...] sus dioses en nombre de un "dios extranjero" y de una razón moderna que ha dado a los conquistadores la legitimidad para conquistar. Es un proceso de racionalización propio de la Modernidad: elabora un mito de su bondad ("mito civilizador") con el que justifica la violencia y se declara inocente del asesinato del Otro (DUSSEL, 1994, p. 68).

2 Por el término estetización, nos referimos a todas las imágenes, vestidos y decoración alrededor de estas festividades que ocultan un fundamento, una hermenéutica simbólica que habremos de desentrañar. Queremos destacar también la enorme fuerza que tiene la imagen del Niñopa, con el ajuar, vestido y juguetes que le acompańan, la gente cree en la fuerza milagrosa de esta imagen. 
La religión hegemónica del conquistador ocultó al "Otro" al sustituir los "ídolos" indígenas por imágenes nuevas, cristianizadas, lo interesante en este intercambio simbólico y semiótico es como éstas nunca se logran asimilar del todo, como lo evidencia el fenómeno de "indigenización de los santos" 3 cuando los mayas de Cozumel, por ejemplo, y del resto del Golfo de México como Campeche y Veracruz, ponen a las imágenes cristianas entre sus ídolos con gran escándalo por parte de los misioneros franciscanos. Una diferencia que hace notar Serge Gruzinski en La guerra de las imágenes es el uso y funciones de los ídolos, mientras que, para los españoles, tienen una relación de teatralidad en el sentido de que se muestran a todos, sagrados y profanos; para los indoamericanos, la imagen siempre está oculta en una cueva, pues consideraban sacrílega su exhibición estética. También, es sumamente interesante que la posición de los españoles en torno a las imágenes de los indios al exportarlas con valor estético a Europa y arrancarlos de su espacio sagrado de sentido, las neutraliza de sus poderes como "ídolos demoníacos" y solo poseen valor como bellezas o maravillas traídas del Nuevo Mundo, pero si se quedan en su espacio de adoración, son ídolos, imágenes falsas o demoníacas que deben ser destruidas según la ideología del conquistador, este es un caso emblemático de lo que Dussel llama el "ocultamiento del indio".

Gruzinski hace un buen acercamiento al fenómeno del comercio o trueque de las imágenes en donde los ídolos indígenas fueron sustituidos por santos cristianos, este efecto de sustitución fue posible gracias a la fuerza energética o milagrosa que estos últimos producen. Por ello, nos dice en su análisis que la postura de Cortés frente a las imágenes paganas fue ambivalente, pues puso altares cristianos para celebrar misas católicas en Templo Mayor, por ejemplo, y empleó sacerdotes paganos como operadores de lo sagrado o "técnicos de lo divino" a falta de sacerdotes católicos, los misioneros eran pocos. Esto último es un caso de expropiación y explotación epistémica, los conquistadores aprovechan la técnica de lo divino de los chamánes para ponerlo al servicio del culto alienante, ahí no les parecían idólatras.

De igual manera, parece contradictorio que los mismos indoamericanos hayan colaborado en la destrucción de sus propias imágenes para sustituirlas por la que les ofrecían los invasores conquistadores, tal vez, como una estrategia de supervivencia.

En el proceso de mestizaje semiótico de finales del siglo XVI y XVII, en la imagen barroca del Niño Jesús conocido por el Niñopa, se dio una codigofagia simbólica en esta imagen con Huitzilopochtli niño, en el sentido de una asimilación en su instauración entre los indoamericanos. En un análisis

3 Término empleado por Feliz Báez-Jorge en Las hagiografias populares y la religiosidad en el México indígena. 
hermenéutico analógico, ${ }^{4}$ podemos decir que ambos dioses son dioses solares, ambos nacen en el solsticio de invierno agrario. Dichos dioses establecían relaciones íntimas con el mundo sobrenatural en el período invernal, una inmovilización de la naturaleza, es por ello que el nacimiento y muerte de estos dioses solares fueran un marcador agrícola y festivo.

Desde un punto de vista teológico "analéctico" 5 en imperios orientales como los de los caldeos, egipcios, cananeos, persas, sirios, fenicios, hindúes; griegos y romanos del occidente, al igual que entre los pueblos de las civilizaciones prehispánicas, como entre los mexicas y los incas, celebraron el solsticio invernal el "parto de la reina de los cielos", así como la llegada al mundo de su hijo, el joven dios solar (PERDIGÓN, 2015).

En el calendario ritual mexica, se celebraba el nacimiento de Huitzilopochtli, comenzaba entre el 3 y 11 de diciembre y terminaba entre el 22 al 30 de igual mes, todo ello coincidía con la Navidad cristiana. La Coatlicue, diosa de la tierra y madre de Huitzilopochtli lo concibió al guardar un montón de plumas caídas del cielo. Era el dios de la guerra, "representaba los dardos y danzas del guerrero, la sabiduría y el poder, símbolos que lo identifican con la serpiente. Pero su nombre alude al colibrí, precursor del verano, la estación de los relámpagos y la fertilidad. ${ }^{6}$

En el mundo prehispánico, las culturas antigüas de Mesoamérica, que se desarrollaron en lo que hoy es la mitad del sur de México y la mitad de Centroamérica, hubo mucas festividades en las que se veneraban a los dioses en su condición infantil. Vaya como ejemplo la festividad que los aztecas llamaban Panquetzaliztli, la cual tenía lugar en el décimo quinto mes del año, dentro de los 18 en que estaba compuesto el calendario. De acuerdo con el padre Sahagún, este mes comenzaba el equivalente al 9 de noviembre y terminaba el 28 del mismo mes. Se trataba de uno de los lapsos más importantes en cuanto a las festividades religiosas, puesto que el último día, o sea el 28, era la conmemoración de Huitzilopochtli [...] Por supuesto que los preparativos para la gran fiesta se iniciaban desde principios del mes (Merlo Juárez en PERDIGÓN, 2015, p. 44).

4 El término hermenéutica analógica esta tomado de la filosofía de Mauricio Beuchot, filósofo y sacerdote dominico mexicano.

5 Usamos el término teología "analéctica" para referirnos a las creencias de las divinidades desde la cosmovisión del "Otro negado" -como sostiene Dussel- por la modernidad europea triunfante del cristianismo después de la caída del Imperio otomano en el Mediterráneo europeo en 1492. Una teología desde el rostro negado desde la periferia y exterioridad, no fueron sino hasta finales del siglo XV, fueron hegemónicos antes de la irrupción histórica de Europa con su "yo conquisto". Las teologías de dioses solares inundaron todo el Mediterráneo, de ahí los cruces hermenéuticos que queremos realizar en esta investigación.

6 Estas precisiones se saben a partir de los escritos del misionero franciscano Bernardino de Sahagún, en su Historia general de las cosas de la Nueva España y la investigación de Duran (PERDIGÓN, 2015, p. 43). 
Los que introducen el culto al Niño Jesús fueron los frailes franciscanos Diego Durán y Bernardino de Sahagún durante el siglo XVI en la Nueva España, ellos nos cuentan en sus crónicas etnográficas acerca de las creencias y ritualidades cosmogónicas de los "naturales" que si, sobre la masa de maíz, el Teocintle sagrado, aparecía la huella de la pisada de un recién nacido, era señal de que el Niño Huitzilopochtli o los dioses habían llegado. Esta creencia en un niño de procedencia divina fue aprovechada por los misioneros franciscanos y, a cambio de esa imagen de la huella de un recién nacido en la masa del maíz, les presentaron a los indígenas la imagen del Niño Jesús en bulto, en brazos de santos y vírgenes e, igualmente, en pinturas al óleo y en los retablos del barroco mexicano que decoran las parroquias y las capillas (AYALA, 2013). Así, empezaron a usarse diversas representaciones del niño Jesús como un instrumento para fomentar la evangelización entre los indígenas en México. Este mestizaje simbólico como estrategia "civilizatoria" de los franciscanos contradice a Robert Ricard en La conquista espiritual de México, quien afirma que los misioneros no aceptaron mezclar en las enseñanzas cristianas ninguna práctica pagana, la investigación etnográfica contradice estas afirmaciones; este mestizaje simbólico fue siempre de ida y vuelta entre vencidos y vencedores, todavía no aparece en escena las regulaciones de las imágenes por el Concilio de Trento de finales del siglo XVI. En la evangelización de principios de siglo, los misioneros debían "convertir" al mayor número y mostrar su eficiencia ante los reyes católicos quienes los han enviado con esa misión. Un método empleado por los franciscanos para lograrlo fue la estética religiosa basada en la teatralización dramática de los pasajes bíblicos. Su efectividad para convertir a los nahuas se debió a que estos ya practicaban dramatizaciones de sus dioses; sin embargo, mientras que los europeos interpretaban estas prácticas como representaciones teatrales, para los indios eran rituales, es decir, era el dios mismo el que se manifestaba. En la estética devocional del Renacimiento europeo en lo representado no está Dios, ni los Santos y Virgen personificados, a diferencia de los nahuas en donde significante y significado van unidos al ser una presencia viva y no semiótica o simbólica el referente está en la escena y no fuera de ella, es la divinidad personificada. El fenómeno analizado a partir de una hermenéutica de la mirada entre europeos e indoamericanos, sus cosmovisiones, parecen hacer un puente de comprensión pero algo permanece oculto a los misioneros, la "criptoreligiosidad-indoamericana", 7 que continuará evolucionando en la "indigenización de las imágenes cristianas" a lo largo de la historia de la Nueva España hasta nuestros días como han mostrado las investigaciones

7 Término propio para referirnos a la lealtad ritual de los indoamericanos a sus divinidades primigenias practicadas bajo la apariencia de la devoción a las imágenes y ritos hegemónicos del cristianismo "vencedor". 
etnográficas de Felix Báez, los investigadores del Colegio Mexiquense y de la ENAH, de ahí que estemos frente a una estética-hermenéutica de liberación.

\section{Estética de la exuberancia en las Cofradías de Xochimilco}

La estética de la abundancia en Xochimilco se observa en la cantidad de manantiales de agua dulce que propició el establecimiento de grupos humanos, se apropiaron del espacio al adaptar sus cultivos y explotar nichos ecológicos que fueron explotados en su producción y se distribuyeron a través de los canales que llegaban hasta el Centro de la Ciudad de México, es así como lograron su supervivencia material reproductiva en la organización de la tierra y la economía. De manera análoga, las Cofradías religiosas permitieron la sobrevivencia simbólica y semiótica de los indígenas a través de una "códigofagia semiótica" como menciona Bolívar Echeverría en su Modernidad de lo Barroco al afirmar que los pueblos prehispánicos fueron heridos de muerte en su centro simbolizador, pero que nunca terminó de morir y, para sobrevivir, tuvo que emplear el código simbólico del dominador, como en este objeto de estudio fue y es la figura del niño Jesús, llamado Niñopa, su origen prehispánico se puede rastrear en el mito de Quetzalcóatl (FLORESCANO, 2000).

En muchos casos, las nuevas estructuras políticas de los pueblos indígenas con sus cargos civiles y religiosos, organizadas por iniciativa de los frailes franciscanos en lo que luego se llamarán "Cofradías", fueron una alternativa a la organización de la encomienda, origen de una terrible práctica genocida de explotación del trabajo indígena, que es conocida por todos; para una extensa revisión de las utopías políticas de estas órdenes de misioneros, se puede revisar nuestra investigación intitulada "[Omitido para dictamen]" en [Omitido para dictaminación]. ${ }^{8}$

Existieron dos instituciones a lo largo del período colonial y jugaron un papel neurálgico en la vida de los pueblos, el cabildo y las cofradías, gracias a ellas podemos conocer su forma de organización económica y política. ¿Qué debemos entender por una cofradía? Según Alicia Bazarte en Las cofradías de españoles y Cruz Rangel en su trabajo Las cofradías novohispanas, podemos definir a la cofradía como una asociación de fieles que se reúnen debido a la devoción católica específica. Estas sirvieron para asistir en lo material y espiritual a sus propios miembros o, dependiendo de su carácter, también podían encaminar sus recursos a obras de beneficio social (PRAXEDIS, 2006, p. 22-23).

Las cofradías resolvieron los problemas de crédito de los indígenas, los cuales encontraron en ellas un acceso a la financiación por medio de las

8 Fuente omitida para dictaminación. 
capellanías, ya que no eran sujetos de crédito. A su vez, estas obtenían los recursos para prestar de la venta de producción de olivos. Este lugar sirvió para que el indígena defendiera y afianzara su identidad a punto de morir, así como un espacio de autonomía y control y, por tanto, de ejercicio de la libertad política. Una identidad basada en la identidad "barroca", la práctica de una resistencia semiótica para evitar ser absorbido por la identidad espańola, la de la "limpieza de sangre" o de un racismo de "blanquitud". El modo de producción era agrícola chinampero, pero "la apropiación del lago requirió primero del control de la zona cerril con sistema de terrazas" (ROJAS, 1993, p. 44).

Todo este contexto económico va acompañado de la estética de la disipación en "[...] lo exuberante en sus manifestaciones festivas y en los cuales los grupos marginales han sabido incorporar su propia visión de la vida y encontrar, por si esto fuera poco, los medios a través de los cuales su existencia toma sentido" (PRAXEDIS, 2006, p. 23). El mestizaje simbólico en los ritos religiosos es fundamental para comprender esta festividad del Niñopa, en primer lugar, los dioses prehispánicos asociados a la naturaleza, el altépetl (agua y cerro), elementos inseparables de la mentalidad indígena. Era considerado el dios tutelar, origen de los pueblos, vivía en las montañas, les abastecía de agua y guiaba los linajes locales. (PRAXEDIS, 2006, p. 34).

También, se creía que el Niño Hutizilopotzli bajaba del cerro y dejaba la huella de su planta sobre la masa del maíz. Los franciscanos, al ver esta práctica, la asociaron al niño Jesús para la aculturación del indio y su conversión religiosa de manera más fluida, como vimos antes.

La zona de Xochimilco, Milpa Alta, San Andrés, la Noria, Santa María Nativitas, tenía una abundancia de manantiales que se formaban dada la porosidad del cerro y la abundancia de agua dulce que generaban de manera espontánea su salida en una multiplicidad de ojos de agua. Esto provocó una disparidad de grupos poblacionales, lo que volvió ingobernable a sus pobladores desde la visión colonialista de los conquistadores, lo cual es sumamente interesante, porque la estética de la exuberancia de estos ojos de agua fue un fenómeno provocado espontáneamente por la misma naturaleza. Les permitió a estos pueblos su supervivencia material, aunque después la territorialidad prehispánica fue vencida por el conquistador, quien trazó nuevos límites geográficos que antes no existían. Todo esto, acompañado de una estética emocional: "con que los afectados por la congregación se mostraron. Los indígenas se dieron cuenta inmediatamente de la dimensión de la amenaza, en ese traslado estaban en juego no sólo los límites de sus pueblos sino la propiedad misma de sus tierras" (GARCÍA MARTÍNEZ en PRAXEDIS, 2006, p. 40).

Si bien las crónicas nos hablan de la supuesta docilidad de los indígenas frente a la evangelización que se dio en Xochimilco, nada hay más falso desde 
una hermenéutica de liberación y de supervivencia simbólica: "detrás de la aparente facilidad con que la nueva fe cristiana ingresó a las mentalidades indias, hay un fuerte proceso de reinterpretación al que el indio recurrió para rescatar lo mejor de su religión [...]" (PRAXEDIS, 2006, p. 65). Existió una estrategia de supervivencia semiótica de sus signos religiosos, pero a la que tienen que recurrir para practicar una "criptoreligiosidad-indoamericana". Es decir, detrás de su práctica devocional católica, subyacen sus antiguos cultos: “[...] y que generaciones posteriores reproducirán sin tener la conciencia de que, detrás de sus devociones, se ocultan antiguas creencias, las cuales, a través de los procesos de reinterpretación y de resistencia cultural, permanecen presentes" (PRAXEDIS, 2006, p. 65).

\section{La imagen barroca del Niñopa y su capital simbólico}

La devoción y adoración de la imagen del Niñopa junto con toda su estetización ritual, posee un capital simbólico que consiste en el quantum energético poseído por las imágenes, el cual sigue acumulándose cada vez que la cofradía y los fieles devotos lo reproducen en su celebración anual. Sus devotos no creen, como en el catolicismo institucional, que la sacralidad de la imagen del santo la instituya el sacerdote como mediador. La imagen de Niñopa es sagrada en sí misma con independencia del sacerdote como operador o técnico de la sacralidad.

El proceso de conformación de este capital simbólico se debe a la elevada relación entre cultura y sacralidad, junto con la carga histórica fundacional con la llegada de los frailes franciscanos en 1524 a la Nueva España, quienes contribuyeron a construirla e intentaron resignificarla hermenéuticamente creando un efecto de sustitución de los dioses prehispánicos por santos cristianos y desplazar a sus antiguos ídolos. Los frailes franciscanos intentaron reconstruir una nueva tradición católica sincretizándola con la religión local prehispánica, en este caso, introdujeron al Niño Jesús en sustitución del Niño Huitzilopotzli, dios de la guerra a quien adoraban los indios mexicas.

El papel de los primeros franciscanos en la Nueva España consistió en cooptar el ritual del grupo para convertir y sustituir su sistema mítico por el del cristianismo, aunque sostenemos la tesis de que continuaron latentes y vivos bajo otra apariencia, su práctica ritual es "contrahegemónica" en su adaptación a sus dioses primordiales, cosmovisiones y la vinculación de la devoción y ritualidad con la reproducción material y social de la comunidad. Los grupos conquistados son variados, pero solo nos referiremos en este caso a los mexicas, tlaxcaltecas y xochimilcas, solo por nombrar a algunos de los primeros grupos, los dos últimos fueron colonizados simbólicamente por los mexicas, de ahí que los xochimilcas adoraran al niño Huitzilopztli siendo un dios solar mexica. 
Los primeros franciscanos en ir a Xochimilco fueron Pedro de Gante en 1523, con Juan Araque y de Aroa, estos dos últimos mueren de hambre en una travesía con Cortés, le siguió fray Martín de Valencia en 1524 junto con el resto de los franciscanos restantes a quienes llamaron los doce apóstoles americanos. Fundaron varios conventos en la región y uno de ellos en Xochimilco llamado San Bernardino de Siena, se desconoce su año de fundación, pero los primeros testimonios de su existencia datan de 1577, dedicado a San Bernardino de Jesús, un franciscano italiano originario de Siena, vivió en el siglo XV y fue un famoso predicador cuyo principal don era la elocuencia y convencía a quien lo escuchara. Es muy probable que este santo fuese elegido patrono de Xochimilco.

Los cronistas de este encuentro de aculturación con los pueblos mexicas, tlaxcaltecas y xochimilcas describen la situación de manera ficcional, lo que su imaginario quería ver y no lo que en realidad era, según Mendieta: "los indios muy principales de esta ciudad, llevaron personalmente sus ídolos ante la presencia de los franciscanos para su destrucción" (PRAXEDIS, 2006, p. 66) No fue una verdadera conversión sino una estrategia de supervivencia y de negociación ante la amenaza de la vida de los indios. Los xochimilcas al llevar sus ídolos a destruir en 1524 frente a fray Martín de Valencia, líder de los doce apóstoles americanos, en realidad solo aparentaban, era una negociación para conservar la vida y no una verdadera conversión:

Los cultos a los antiguos dioses se siguieron practicando en montes, lagunas y cuevas, o en los lugares donde habían existido templos prehispánicos. En muchas ocasiones los frailes habían construido los nuevos templos cristianos sobre las ruinas de los antiguos. (PRAXEDIS, 2006, p. 66).

Muy pronto se dieron cuenta de que detrás de las aparentes devociones católico cristianas había una práctica encubierta que llamaremos "criptoreligiosidad-indoamericana" de los antiguos ritos paganos De entre los diversos cultos devocionales que se practicaron en Xochimilco, sobresale el del Niñopa, su mayordomía tiene más de 200 años. Esta divinidad que corporalmente se asemeja al cuerpo humano se construyó a partir de prácticas ritualizadas con el catolicismo oficial que se da en contextos histórico-culturales determinados. El ritual va articulado con un concepto de cuerpo y cosmovisión del mundo nahua mezclado en la vida colectiva, las cosmovisiones en el mundo mesoamericano son modelos que poseen tres "mundos", realidad interdependiente y unificada para estos pueblos. Para comprenderlos, debemos ponernos en sus zapatos y no juzgarlos desde nuestra propia religiosidad, si no, se nos oculta el significado de la devoción del Niñopa. De ahí que necesitamos apoyarnos en los etnógrafos y antropólogos: 
Las cosmovisiones dan un modelo para actuar en el mundo natural, animado y vivo, el mundo humano social, y el mundo sobrenatural poblado de un sinnúmero de entes. Esto quiere decir que los sucesos del mundo sobrenatural inciden en la comunidad humana, igual que los sucesos en el mundo sobrenatural y natural se influyen mutuamente. Los principios de la cosmovisión indican cómo los humanos deben actuar desde su propia esfera, y también cómo interactuar con las otras para mantener el funcionamiento equilibrado y armonioso, del cosmos (GOOD, 2015, p. 148).

Las cosmovisiones son procesos dinámicos de adaptación en las relaciones sociales, económicas y rituales, no están separadas, por eso vemos, en esta devoción del Niñopa, estas tres dimensiones también. No es como hemos venido sosteniendo una devoción meramente católica, sino que posee toda esta cosmovisión como su génesis.

La significación del Niñopa como niño del lugar para referirse a la huella que el Huitzilopochtli niño deja en la masa de maíz y como la ritualidad y estética de su devoción ya sincretizada como Niño Jesús, tiene que ver con el significado de la vida de reproducción social y anímica de un pueblo, como son las nociones de trabajo (tequitl) y fuerza (chicahualiztli). En la vida social y ritual indígena se mezclan dos nociones inseparables, el trabajo y la reciprocidad del intercambio de bienes, los cuales están espiritualizados por ser expresión del amor y el respeto, poseen una energía vital que fluye mediante el intercambio, la distribución, el ritual y la fiesta y sirve a la reproducción de la identidad cultural colectiva (GOOD, 2015, p. 150-151).

Estas relaciones de intercambio son entre los vivos y los muertos, los agricultores y la tierra (que es concebida como algo vivo y anímico), los humanos y el maíz, entre los santos (Niñopa) y el pueblo, las comunidades y los puntos sagrados.

Este es el significado de la ritualidad encerrada en la devoción a los santos, en el caso particular del Nińopa se incorporan, como hemos venido sosteniendo, elementos de cosmovisiones ancestrales y evidencian desde nuestro punto de vista, manifestaciones contrahegemónicas de esta religiosidad popular que tiende a la simbología mítica más que a los formalismos rituales de la Iglesia Católica.

En estas riquísimas vetas del imaginario colectivo, personajes míticos y deidades primigenias se asocian o fusionan (de manera selectiva) con los santos, con diversas advocaciones marianas y con la imagen de Jesucristo, asumida desde distintas perspectivas. Se configura así una compleja criba simbólica dimensionada en el tiempo mítico y en acontecimientos de la historia local, al margen del canon y del control eclesiástico (BAEZ-JORGE, 2015, p. 304). 
Es un error, según Félix Báez, considerar las hagiografías de los santos como "catolicismo popular", pues las historias de los santos y su representación en imágenes y su devoción sufren un proceso de significación basado en múltiples factores, desde fenómenos sobrenaturales hasta razones existenciales de privación y de obtención de bienes de subsistencia o de salud comunitaria: "Tienen como foco de atención los espacios sagrados locales, la integración y cohesión social y la tradición mítica articulada en su visión del mundo" (BAEZ-JORGE, 2015, p. 306).

Consideramos que, en la devoción del Niñopa, existen dos niveles hermenéuticos simbólicos, uno estético que refiere a su apariencia superficial y obedece a los complejos procesos de ideologización del cristiananismo hegemónico y otro, ontológico, refiere a sus vínculos con raíces muy profundas de significación como sus lealtades a creencias particulares de corte mítico. Esto es lo que hemos denominado "criptoreligiosidad-indoamericana", es decir, dentro de las formas aparentes de ritualidad cristiana subyacen sus raíces míticas ancestrales, ligadas al dios solar y de la guerra llamado Huitzilopochtli y el maíz, la relación con la tierra, abundancia de bienes y la salud de la comunidad. De igual manera, la estética festiva de la devoción del Niñopa funciona como dos tipos de expresión, identitaria, pero también de voluntad de poder local y contrahegemónica.

Los escenarios fantásticos en los que se desarrollan las vidas de los santos venerados en las comunidades indígenas poco (o nada) tienen en común con los contextos geográficos, históricos y sociales establecidos en las hagiografías difundidas por la institución eclesiástica (BAEZ-JORGE, 2015, p. 307).

En este sentido, estamos frente a una estética-hermenéutica de liberación y un mestizaje simbólico de supervivencia que comienza en el siglo XVI cuando los mexicas, al ver destruidos sus centros de religiosidad política, los cuales habían sido aniquilados por la voluntad "civilizatoria" ibérica, terminaron por depender de las instituciones político religiosas de los europeos para mantenerse con vida. Sus sistemas simbólicos y semióticos de relación con la naturaleza no terminaban de morir y agonizantes tuvieron que recurrir al mestizaje religioso en las imágenes barrocas del siglo XVII en la Nueva España.

\section{Hermenéutica-estética festiva devocional del Niñopa y su reproducción energética}

¿En qué consiste el elemento festivo del Niñopa? En una invasión disruptiva del automatismo cotidiano y transfigurador de lo real, donde lo necesario aparece como contingente, el mundo no refleja escasez sino abundancia y plenitud, se vive en el dispendio del tiempo y de los bienes, 
la experiencia de un tiempo improductivo "fuera de sî", es decir, fuera de la exigencia productivista del "estar en sî" y ligado a la represión. El dispendio festivo es resistencia, un simulacro del "como sî", un juego o vaivén de "destrucción-reconstrucción", de "caos-orden". El momento festivo es condición de posibilidad del "en sî" productivista, nos dice Echeverría, la vida se libera de su compulsión productivista y rompe con la domesticación de las formas, eso es justo lo que comparten como elemento los rituales religiosos de estas Cofradías administrando la Fe; son instantes de gasto improductivo, una lujosa ruptura del "continuum" mediante una dimensión lúdica, festiva y estética. Esta devoción xochimilca es una inversión de la realidad cotidiana en un mundo transfigurado durante la fiesta, una invasión disruptiva del automatismo cotidiano.

Un buen ejemplo de estos modos de ser festivos y de celebración son analizados por Katya Mandoki en "Estética de la disipación" (MANDOKI, 2013, p. 97-106), donde estudia los rituales y fiestas de los habitantes de las islas trobriandesas, llamados kula o potlatch , en donde la comunidad disipa bienes en lugar de acumularlos, los regala a la comunidad por considerarlo un signo de distinción y poder entre los pueblos, en la creencia de que los objetos contienen el espíritu de su hacedor, una especie de espíritu que los contiene, un "hau" o espíritu de las cosas. Según descubre Mauss en su investigación económica acerca de estos pueblos, las cosas retienen el alma de su creador o de su hacedor y puede ser destructivo si no se lo reconoce: "los maoríes llaman hau a este espíritu que se aferra a un objeto cuando cambia de propietario; por lo tanto, uno debe relacionarse con esta presencia concreta de los objetos cuando se les introduce en el hogar" (MANDOKI, 2013, p. 100),

En los rituales festivos de estos pueblos, reconocemos este momento del "espíritu de las cosas", su "hau", su ser prefigurativo y figurativo del proceso creativo, una mímesis del dispendio festivo. Podemos emplear las teorías de Echeverría y Mandoki para analizar esta estetización visual como una hermenéutica cultural de resistencia política-simbólica, la estetización ritual del Niñopa es una defensa de las formas naturales, es decir, del valor histórico del lugar, de las comunidades xochimilcas con todo el mestizaje simbólico que conlleva y cómo este santo conserva el "hau" o espíritu de la tradición y de toda su carga salvífica, lo consideran muy milagroso y el retenerlo y tocar su ropón, pues está prohibido tocarlo, es suficiente para recibir toda la carga energética acumulada durante siglos de devoción. El niño Dios ha acumulado, como capital simbólico y de reproducción energética, todo lo que la gente le ha querido regalar, por ello, su cuarto en la casa del mayordomo debe ser amplio, lo que sí se dispendia es en la fiesta para toda la comunidad, se dispendian bienes materiales como un intercambio de capital material por capital simbólico y semiótico (MANDOKI, 2013, p. 313). 
La estetización ritual del Niñopa es una forma de revalorar ese "hau" o espíritu de la comunidad xochimilca que emplea su corporalidad en la exuberancia y exceso alegre de la vida de la fiesta. Esta última se compone de bailes, como el de los chinelos; alimentos típicos como el mole, los tamales, el atole, los elotes; además de los cohetes, el canto, la procesión y la devoción. La adoración a Dios va acompañada de una estética emotiva en la comunidad, llorar, abrazar, demostrar la humildad devocional en una entrega absoluta, con lo cual se afianza la identidad política simbólica de los xochimilcas. Estamos frente a una estética de exceso, de gasto impune del tiempo en gasto improductivo, la de un tiempo pleno, extraordinario y prefigurativo, informe, sin determinación, sin límites, sin estar al servicio del trabajo. Un tiempo lleno de vida significativa, en donde la humanidad se afianza en su sentido como ser de narrativa, su construcción simbólica. El devoto se conecta con su sensibilidad y corporalidad propia, recuperada, un cuerpo despierto, frenado de su compulsión productivista de entrega sacrificada al trabajo ordinario y ahora empleado en el exceso festivo, dueño de su forma y esa es políticasemiótica-simbólica. Una estetización ritual que me dice que la vida me está disponible, como define Dussel el concepto de estética.

\section{Conclusiones}

Esta investigación logró probar cómo la práctica devocional del Niñopa es un caso ejemplar de "contrahegemonía ritual" frente al catolicismo institucional y, por tanto, es un error ubicar la devoción del Niñopa como expresión del "catolicismo popular", el análisis crítico nos permitió esquematizar dicha devoción dentro de la estética y hermenéutica de la liberación, una forma de vida barroca y una estética disruptiva de dispendio festivo en lugar de acumulación de riqueza. Todo ello refuerza la prueba de su práctica contrahegemónica, pudimos llegar a esta conclusión gracias a la revisión genealógica de la construcción de la devoción fundada en la lealtad de los indoamericanos a los dioses prehispánicos en la infancia de los dioses solares, como el caso del Niño Huitzilopochtli, esto gracias a la revisión etnográfica y antropológica acerca de este objeto de estudio. La investigación trató de probar sus hipótesis a partir de una metodología de análisis estético-hermenéutico con las categorías teóricas derivadas de la filosofía de la liberación de Enrique Dussel, la hermenéutica de la cultura de Bolívar Echeverría y la estética de la vida cotidiana de Katya Mandoki. 


\section{Referencias}

AYALA Cerecedo, Tania Ivette. "El Niñopa: Descripción Etnográfica y Análisis de la Escenificación y Representación de los Rituales que le rodean”, Iztapalapa, México: UAM, 2013.

DUSSEL, Enrique. El Encubrimiento del otro: Hacia el Origen del Mito de la Modernidad. México: Editorial Cambio XXI / Colegio Nacional de Ciencias Políticas y Administración, 1994.

DUSSEL, Enrique. Filosofía de la producción. Bogotá: Editorial Nueva América, 1985.

ECHEVERRÍA, Bolívar. Modernidad y blanquitud. México: ERA, 2010.

ECHEVERRÍA, Bolívar. La modernidad de lo barroco. México: ERA, 2000.

FLORESCANO, Enrique. El mito de Quetzalcóatl. Ciudad de México: Fondo de Cultura Económica, 2000.

BAEZ-JORGE, Félix. "Las hagiografías populares y la religiosidad en el México indígena”. En Cosmovisión mesoamericana. Reflexiones, polémicas y etnografías. Gámez Alejandra y López Austin Alfredo (coords.). México: Fondo de Cultura Económica, 2015.

GOOD Eshelman, Catharine. "Las cosmovisiones, la historia y la tradición intelectual en Mesoamérica”. En Cosmovisión mesoamericana: Reflexiones, polémicas y etnografía. Alejandra Gámez y Alfredo López Austín (coord.). México: Fondo de Cultura Económica, 2015.

GRUZINSKI, Serge. La guerra de las imágenes: De Cristóbal Colón a "Blade Runner" (1492-2019). Ciudad de México: Fondo de Cultura Económica, 1994.

MANDOKI, Katya. El indispensable exceso de la Estética. México: Siglo XXI, 2013.

PERDIGÓN, Judith. Mi Niño Dios: Un acercamiento al concepto, historia, significado y celebración del Niño Jesús para el Día de la Candelaria, Colección Etnología y Antropología Social, Instituto Nacional de Antropología e Historia 75 aniversario, México, 2015.

PRAXEDIS, Joaquín. La Administración de la Fe: Cofradias de Xochimilco, siglo XVIII. Delegación Xochimilco, México: Gobierno del Distrito Federal, 2006.

QUIJANO, Aníbal. "Poder y derechos humanos”. En: Poder, Salud Mental y Derechos Humanos. Carmen Pimentel Sevillana (Ed.). Lima, Perú: CECOSAM, 2001, p. $9-25$.

ROJAS Rabiela, Teresa (comp.). La agricultura chinampera. México: Universidad Autónoma de Chapingo, 1993. 
María Cristina Ríos Espinosa. Doctora en Filosofía por la Universidad Nacional Autónoma de México, (UNAM, 2006). Miembro del Sistema Nacional de Investigadores del Consejo Nacional de Ciencia y Tecnología, CONACYT. Estancia de investigación en la Facultad de Filosofía de la Universidad Complutense de Madrid (2005). Maestra en Filosofía por la UNAM (2001). Profesora investigadora de tiempo completo en el Colegio de Arte y Cultura de la Universidad del Claustro de Sor Juana. Miembro de la Asociación Filosófica de México. Coordinadora editorial de Cuadernos Amest \#2 y \#3 y coautora de Cuadernos Amest \#1, \#2 y \#4. Coordinadora y coautora de libro Reflexiones en torno al ser del arte, Universidad Iberoamericana, México, 2013 y del libro Revolución de Independencia e identidad cultural, AMEST, 2013.

E-mail: m.riose@universidaddelclaustro.edu.mx 